\title{
Purification and characterization of microbial protease produced extracellularly from Bacillus subtilis FBL-1
}

Article

Accepted Version

Si, J.-B., Jang, E.-J., Charalampopoulos, D. and Wee, Y.-J. (2018) Purification and characterization of microbial protease produced extracellularly from Bacillus subtilis FBL-1.

Biotechnology and Bioprocess Engineering, 23 (2). pp. 176182. ISSN 1226-8372 doi: https://doi.org/10.1007/s12257-0170495-3 Available at https://centaur.reading.ac.uk/78941/

It is advisable to refer to the publisher's version if you intend to cite from the work. See Guidance on citing.

Published version at: http://dx.doi.org/10.1007/s12257-017-0495-3

To link to this article DOI: http://dx.doi.org/10.1007/s12257-017-0495-3

Publisher: Springer

All outputs in CentAUR are protected by Intellectual Property Rights law, including copyright law. Copyright and IPR is retained by the creators or other copyright holders. Terms and conditions for use of this material are defined in the End User Agreement.

www.reading.ac.uk/centaur 
Central Archive at the University of Reading

Reading's research outputs online 


\section{Purification and characterization of microbial protease produced}

\section{2 extracellularly from Bacillus subtilis FBL-1}

3

4

Jin-Beom Si, Eun-Ju Jang, Dimitris Charalampopoulos, Young-Jung Wee

5

6 Jin-Beom Si, Eun-Ju Jang, Young-Jung Wee*

7 Department of Food science and Technology, Yeungnam University, Gyeongsan, Gyeongbuk

$8 \quad 38541$, Republic of Korea

9 Tel: +82-53-810-2951; Fax: +82-53-810-4662

10 E-mail: yjwee@ynu.ac.kr

12 Dimitris Charalampopoulos

13 Department of Food and Nutritional Sciences, University of Reading, Whiteknights, P.O. Box

14 226, Reading, RG6 6AP, United Kingdom

16 Abstract An ammonium sulfate precipitation of fermentation broth produced by Bacillus

17 subtilis FBL-1 resulted in 2.9-fold increase of specific protease activity. An eluted protein 
18 fraction from the column chromatographies using DEAE-Cellulose and Sephadex G-75 had

19 94.2- and 94.9-fold higher specific protease activity, respectively. An SDS-PAGE revealed a

20 band of purified protease at approximately $37.6 \mathrm{kDa}$. Although purified protease showed the

21 highest activity at $45^{\circ} \mathrm{C}$ and $\mathrm{pH} 9.0$, the activity remained stable in temperature range from

$2230^{\circ} \mathrm{C}$ to $50^{\circ} \mathrm{C}$ and $\mathrm{pH}$ range from 7.0 to 9.0 . Protease activity was activated by metal ions

23 such as $\mathrm{Ca}^{2+}, \mathrm{Mg}^{2+}, \mathrm{Mn}^{2+}, \mathrm{Fe}^{2+}, \mathrm{Ca}^{2+}$ and $\mathrm{K}^{+}$, but $10 \mathrm{mM} \mathrm{Fe} \mathrm{F}^{3+}$ significantly inhibited enzyme

24 activity (53\%). Protease activity was inhibited by $2 \mathrm{mM}$ EDTA as a metalloprotease inhibitor,

25 but it showed good stability against surfactants and organic solvents. The preferred substrates

26 for protease activity were found to be casein (100\%) and soybean flour (71.6\%).

28 Keywords: protease; Bacillus; metalloprotease; organic solvent; purification

30 1. Introduction

32 Proteases (E.C.3.4.21-24) catalyze the cleavage of peptide bond in protein molecules

33 resulting in smaller fragments such as peptides and/or amino acids. They are distributed

34 broadly in nature and a wide variety of microorganisms. Proteases are usually divided into 
35 two groups, exopeptidases or endopeptidases, depending on their site of hydrolysis.

36 Exopeptidases break the peptide bonds formed between the end amino acid and the rest of

37 peptide chain, but endopeptidases hydrolyze the peptide bonds found within the polypeptide

38 or protein. There was an attempt to classify proteases based on structural features of enzyme

39 active center, rather than origin, specificity, or physiological action [1]. Proteases are then

40 divided into four classes based on the type of functional group present at the active site and

41 their mechanism of action: 1) serine protease, 2) aspartic protease, 3) cysteine/thiol protease,

42 and 4) metalloprotease [1,2].

43 Proteases are extensively used in a variety of industries, including detergent, leather,

44 pharmaceuticals, food, textile, bakery, soy-processing, peptide synthesis, and X-ray film. The

45 estimated value of worldwide sales of enzymes has been over 3 billion U.S. dollars, and the

46 market for proteases accounts for approximately $60 \%$ of the total worldwide sale of enzymes

47 [3-6]. Proteases have been isolated, purified, and identified in living organisms and bacteria.

48 Microorganisms are good source of proteases due to a number of advantages; 1) the broad

49 biochemical diversity, 2) the rapid growth, 3) the limited space required for cell cultivation,

50 and 4) the ease at which the enzymes can be genetically manipulated to generate new

51 enzymes for various applications [3]. Some bacteria, yeasts, and fungi are able to produce 
52 proteases, but only those microorganisms that produce enough amounts of extracellular

53 proteases are of industrial importance [7]. Microbial proteases are widely different not only in

54 their functions but also in their properties.

55 Recently, most of the industrial processes are carried out at harsh conditions, where the

56 enzymes are unstable under extremely high temperature, high or low $\mathrm{pH}$, high concentration

57 of organic solvents and detergents, but only a limited class of proteases is recognized as

58 commercial resource. Alkaline serine proteases such as subtilisin Carlsberg, subtilisin BPN',

59 and Savinase are the major application as detergent industrial source, and some

60 metalloproteases are usually used in brewing and therapeutic industry [6].

61 We have successfully isolated and examined B. subtilis FBL-1 to produce potential

62 protease $[7,8]$. One of the possible objectives of purifying and characterizing a bacterial

63 protease has been the production of enzymes for commercial purposes. Therefore, in the

64 present study, a bacterial protease was produced by B. subtilis FBL-1, which was then

65 purified and characterized by ammonium sulfate precipitation, column chromatographies, and

66 SDS-PAGE. In addition, enzymatic properties of the purified protease were further

67 investigated to characterize the effects of enzyme activity and stability on organic solvents,

68 detergents, temperature, $\mathrm{pH}$, oxidizing agents, and reducing agents. 
70 2. Materials and Methods

\subsection{Bacterial strain}

74 Bacillus subtilis FBL-1 KCCM 43196 isolated from soil was procured by Food

75 Bioengineering Laboratory in Yeungnam University, Daegu, South Korea [7, 8]. Stock

76 cultures were preserved in $1.5 \mathrm{~mL}$ sample tubes containing $50 \%(\mathrm{v} / \mathrm{v})$ glycerol at $-70^{\circ} \mathrm{C}$ until

77 use. In order to activate cultures, strains were inoculated into tryptic soy broth (TSB; BD,

78 Sparks, MD, USA) and then grown at $37^{\circ} \mathrm{C}$ and $200 \mathrm{rpm}$ for $15 \mathrm{~h}$.

\section{$80 \quad$ 2.2. Production of protease}

82 The cells from stock cultures were inoculated to sterile $100 \mathrm{~mL}$ growth medium (TSB) and

83 dispensed into $250 \mathrm{~mL}$ Erlenmeyer flasks, followed by incubation at $37^{\circ} \mathrm{C}$ for $15 \mathrm{~h}$. This was

84 then inoculated aseptically at $1.5 \%(\mathrm{v} / \mathrm{v})$ into $250 \mathrm{~mL}$ Erlenmeyer flask containing $100 \mathrm{~mL}$

85 production medium, which were incubated on a shaking incubator (VS-8480SF; Vision 
86 Scientific Co., Daejeon, Korea) at $37^{\circ} \mathrm{C}$ and $200 \mathrm{rpm}$. The production medium was composed

87 of $32.4 \mathrm{~g} / \mathrm{L}$, yeast extract $15.0 \mathrm{~g} / \mathrm{L}, \mathrm{KH}_{2} \mathrm{PO}_{4} 1.0 \mathrm{~g} / \mathrm{L}$, and $\mathrm{MgSO}_{4} \cdot 7 \mathrm{H}_{2} \mathrm{O} 0.6 \mathrm{~g} / \mathrm{L}$. After $36 \mathrm{~h}$ of 88 cultivation, cells were centrifuged at $13,000 \times g$ and $4{ }^{\circ} \mathrm{C}$ for 15 min with a high-speed 89 refrigerated centrifuge (Supra 21K; Hanil Scientific Inc., Gimpo, Korea). The supernatant 90 was collected and used as a crude enzyme preparation.

94 Protease activity was measured using casein as a substrate by the modified Folin \& 95 Ciocalteu's method [9]. A $20 \mu \mathrm{L}$ of the enzyme was mixed with $500 \mu \mathrm{L}$ of $0.5 \mathrm{M}$ glycine$96 \mathrm{NaOH}$ buffer ( $\mathrm{pH} 9.0)$ containing $1 \%(\mathrm{w} / \mathrm{v})$ casein and incubated at $40^{\circ} \mathrm{C}$ for 10 min with 97 control. The enzyme reaction was stopped by addition of $2 \mathrm{~mL}$ of $10 \%(\mathrm{w} / \mathrm{v})$ trichloroacetic 98 acid. The mixture was incubated at room temperature for $15 \mathrm{~min}$, followed by centrifuged at $9916,000 \times g$ for $15 \mathrm{~min}$. The supernatant was mixed with $2.5 \mathrm{~mL}$ of $0.5 \mathrm{M} \mathrm{Na}_{2} \mathrm{CO}_{3}$ and then $100500 \mu \mathrm{L}$ of $20 \%(\mathrm{v} / \mathrm{v}) 2 \mathrm{~N}$ Folin \& Ciocalteu's reagent was added. The mixture was incubated 101 at $40^{\circ} \mathrm{C}$ for $10 \mathrm{~min}$ then the absorbance of mixture at $660 \mathrm{~nm}$ was measured by a 102 spectrophotometer (UV-1600; Shimadzu Co., Kyoto, Japan). One unit of enzyme activity was 
defined as the amount of enzyme required to liberate $1 \mu \mathrm{g}$ of tyrosine per minute under the

standard assay conditions.

\subsection{Measurement of protein concentration}

107

Protein concentration was determined by the BCA (bicinchonic acid) method using bovine serum albumin as a standard [10]. During chromatographic purification steps, the protein content of each fraction was monitored by measuring the absorbance at $280 \mathrm{~nm}$.

\subsection{Enzyme purification}

Culture supernatant was subjected to ammonium sulfate precipitation for purification of protease. Ammonium sulfate fractions of $30-80 \%$ were collected by centrifugation at 13,000

$\times g$ and $4{ }^{\circ} \mathrm{C}$ for $60 \mathrm{~min}$, and the pellet was dissolved in a minimum amount of $0.1 \mathrm{M}$ Tris-

$1 \mathrm{HCl}$ buffer ( $\mathrm{pH}$ 7.0). The protein was dialyzed against the same buffer to remove the residual salt at $4{ }^{\circ} \mathrm{C}$ overnight with changing buffer solution. The dialysate was loaded onto a DEAECellulose column $(15 \times 300 \mathrm{~mm})$, which was equilibrated with $0.1 \mathrm{M}$ Tris-HCl buffer $(\mathrm{pH}$ 
120 7.0). Proteins were eluted with a linear gradient of $\mathrm{NaCl}(0-0.5 \mathrm{M})$ dissolved in the same

121 buffer, and each fraction of $2.0 \mathrm{~mL}$ was collected. The column was washed with the same

122 buffer until the absorbance of effluent at $280 \mathrm{~nm}$ reached zero. Enzyme activity and protein

123 concentration of each fraction were measured. After then, the resultant fractions showing

124 protease activity were loaded onto a Sephadex G-75 column $(15 \times 300 \mathrm{~mm})$, which was

125 equilibrated with $100 \mathrm{mM}$ Tris- $\mathrm{HCl}$ buffer $(\mathrm{pH}$ 7.0). The fractions of $1 \mathrm{~mL}$ each were

126 collected, and enzyme activity and protein concentration were measured. All purification

127 procedures were carried out at $4^{\circ} \mathrm{C}$.

128 Sodium dodecyl sulfate-polyacrylamide gel electrophoresis (SDS-PAGE) on a 5\% staking

129 gel and a $12 \%$ resolving gel was used to determine the purity and molecular weight of the

130 enzyme by the method of Laemmli [11]. Protein bands were visualized by silver staining

131 method. Molecular weight of the purified enzyme was estimated by comparing the relative

132 mobility of standard molecular weight marker protein (Bio-rad, Hercules, CA, USA).

$134 \quad$ 2.6. Effect of $\mathbf{p H}$ on protease activity and stability

136 The effect of $\mathrm{pH}$ on protease activity was measured at different $\mathrm{pH}$ values. The $\mathrm{pH}$ of the 
137 reaction mixture was adjusted to the desired values by using $0.1 \mathrm{M}$ of buffers containing $1 \%$ (w/v) casein as a substrate as follows; citric acid buffer ( $\mathrm{pH} 3.0$ to 5.0), phosphate-citrate buffer ( $\mathrm{pH} 5.0$ to 7.0), Tris-HCl buffer ( $\mathrm{pH} 7.0$ to 9.0), and glycine-NaOH buffer (pH 9.0 to 140 12.0). The $\mathrm{pH}$ stability of protease was determined by pre-incubation in the above mentioned 141 buffers at room temperature for $30 \mathrm{~min}$ and $60 \mathrm{~min}$. The relative activity of enzyme was 142 quantified under the standard assay conditions.

\subsection{Effect of temperature on protease activity and stability}

The effect of temperature on protease activity was carried out by incubation of reaction mixture at different temperatures ranged between $30^{\circ} \mathrm{C}$ and $60^{\circ} \mathrm{C}$ in $0.5 \mathrm{M}$ glycine- $\mathrm{NaOH}$ buffer ( $\mathrm{pH} 9.0)$ containing $1 \%(\mathrm{w} / \mathrm{v})$ casein as a substrate. Thermal stability of the protease was determined by pre-incubation of protease at $30-70^{\circ} \mathrm{C}$ for $30 \mathrm{~min}$ and $60 \mathrm{~min}$. The relative activities were quantified under the standard assay conditions.

\subsection{Substrate specificity}


154 Substrate specificity of the protease was determined using different substrates. The reaction mixtures were prepared by adding $1 \%(\mathrm{w} / \mathrm{v})$ of casein, bovine serum albumin (BSA), soybean 156 flour, and gelatin in $0.5 \mathrm{M}$ glycine- $\mathrm{NaOH}$ buffer $(\mathrm{pH}$ 9.0). The enzyme activity was 157 determined as described above.

\subsection{Effect of metal ions on protease activity}

The effect of metal ions on enzyme activity was investigated by incubating the reaction 162 mixture with $\mathrm{NH}_{4} \mathrm{Cl}, \mathrm{CaCl}_{2} \cdot 2 \mathrm{H}_{2} \mathrm{O}, \mathrm{FeCl}_{3} \cdot 6 \mathrm{H}_{2} \mathrm{O}, \mathrm{FeSO}_{4} \cdot 7 \mathrm{H}_{2} \mathrm{O}, \mathrm{MgSO}_{4} \cdot \mathrm{H}_{2} \mathrm{O}, \mathrm{MnCl}_{2} \cdot 4 \mathrm{H}_{2} \mathrm{O}$,

$\mathrm{KCl}, \mathrm{CaCO}_{3}$, and $\mathrm{ZnCl}_{2}$ at concentrations of $1 \mathrm{mM}$ and $5 \mathrm{mM}$ for $30 \mathrm{~min}$ and $60 \mathrm{~min}$ at room temperature, respectively. The enzyme activity measured under the absence of metal ions was considered as $100 \%$.

\subsection{Effect of detergents, oxidants, and reductants on protease activity}

The enzyme solution was incubated at room temperature for $30 \mathrm{~min}$ in $0.5 \mathrm{M}$ glycine- $\mathrm{NaOH}$ buffer (pH 9.0), containing 1\% (v/v) Tween 20, $1 \%(\mathrm{v} / \mathrm{v})$ Tween 80, $1 \%(\mathrm{v} / \mathrm{v})$ Triton X-100, 1 
$\mathrm{mM}$ and $10 \mathrm{mM}$ sodium dodecyl sulfate, $2 \%(\mathrm{v} / \mathrm{v}) \mathrm{H}_{2} \mathrm{O}_{2}$, and 2\% (v/v) 2-mercaptoethanol.

172 Esterase activity was assayed by the spectrophotometric method and compared with the 173 activity of the enzyme in the absence of detergent. Protease activity was measured and 174 compared with the proteolytic activity of the enzyme in the absence of surfactants, oxidants, 175 and reductants.

\subsection{Effect of organic solvents on protease activity}

The enzyme solution was incubated at room temperature for $30 \mathrm{~min}$ in in $0.5 \mathrm{M}$ glycine-

$\mathrm{NaOH}$ buffer ( $\mathrm{pH} 9.0)$, containing 25 or $50 \%$ (v/v) of 1-butanol, benzene, $n$-hexane, 2181 propanol, dimethyl sulfoxide (DMSO), and ethyl alcohol. Tween 80 was used as an 182 emulsifier for water-immiscible solvents. Protease activity was measured and compared with 183 the proteolytic activity of the enzyme in the absence of organic solvents.

\section{$185 \quad$ 2.12. Effect of inhibitors on protease activity}

The effect of several inhibitors on protease activity was investigated by incubating the 
enzyme solution with ethylenediaminetetraacetic acid (EDTA, $2 \mathrm{mM}$ and $10 \mathrm{mM}$ ), phenylmethylsulfonyl fluoride (PMSF, $1 \mathrm{mM}$ ), and diisopropyl fluorophosphates (DIFP, 0.1

$190 \mathrm{mM}$ ). The purified enzyme was pre-incubated with each inhibitor at room temperature for 30

$191 \min$ and then the residual activity was measured under the standard assay condition.

\section{Results and Discussion}

\subsection{Purification of protease}

B. subtilis FBL-2 was cultivated in optimized medium for $36 \mathrm{~h}$. The crude enzyme 198 preparation was subjected to $30-80 \%$ ammonium sulfate precipitation, followed by dialyzed 199 against $0.1 \mathrm{M}$ Tris- $\mathrm{HCl}$ buffer $(\mathrm{pH} 7.0)$ at $4{ }^{\circ} \mathrm{C}$ overnight by changing the fresh buffer every 4 200 h. The dialyzate was loaded onto DEAE-Cellulose column at a flow rate of $2 \mathrm{~mL} / \mathrm{min}$. As 201 shown in Fig. 1A, the fractions showing high protease activity (Fractions 5 to13) were pooled, 202 desalted, concentrated, and loaded again onto Sephadex G-75 column. Fractions 15 to 38 203 showed high protease activity (Fig. 1B). Purification factors and recoveries at each step are 204 shown in Table 1 . The enzyme was purified 94.89 -fold with a yield of $2.3 \%$ from the crude 
extract, and the specific activity was increased to $3378.1 \mathrm{U} / \mathrm{mg}$-protein.

Molecular weight of the purified protease was verified by SDS-PAGE and silver staining method. As shown in Table 1, after ammonium sulfate precipitation step, the recovery ratio of 208 protein and enzyme were as low as $2.5 \%$ and $7.1 \%$, respectively. In addition, ammonium 209 sulfate precipitation resulted in more concentrated proteins other than protease. This low 210 amount of recovery for a target enzyme and low selectivity of ammonium sulfate 211 precipitation might result in denser protease band of crude extract than that of ammonium 212 sulfate fraction (Fig. 2). However, the protease was dramatically purified in the next 213 chromatographic separation steps, which was visualized in Fig. 2. By comparing the relative 214 mobility of standard marker proteins, molecular weight of the purified protease was estimated 215 to be approximately $37.6 \mathrm{kDa}$, which was similar to molecular weight of protease derived 216 from B. subtilis RKY3 (38 kDa) [12].

\section{$218 \quad$ 3.2. Effect of $\mathbf{p H}$ on protease activity and stability}

220 The effect of $\mathrm{pH}$ on protease activity and stability was examined over a $\mathrm{pH}$ range from $\mathrm{pH}$ 2213.0 to 12.0 . As shown in Fig. 3A, enzyme showed the highest activity at pH 9.0 (glycine- 
$\mathrm{NaOH}$ buffer), but it was declined rapidly beyond $\mathrm{pH}$ 9.0. As shown in Fig. 3B, the purified enzyme was stable between $\mathrm{pH} 7.0$ and 9.0 for 30 and $60 \mathrm{~min}$, respectively. In addition, the enzyme activity could be retained approximately $80 \%$ of its initial activity at $\mathrm{pH} 6.0$ to 9.0 225 after incubation for $30 \mathrm{~min}$. Similar results of $\mathrm{pH}$ effect on protease activity have been 226 reported, and the proteases produced by B. subtilis Y-108 [13], B. tequilensis P15 [14], B. 227 cereus SV1 [15], and B. cereus AK1871 [16] showed their optimum pH at 7.5 to 8.0 and high $228 \mathrm{pH}$ stability at 7.0 and 9.0 .

The effect of temperature on protease activity was investigated. As shown in Fig. 4A, the 233 protease activity was highest at $45^{\circ} \mathrm{C}$, and the enzyme activity at $50^{\circ} \mathrm{C}$ was sustained with $23498.5 \%$ of maximum activity. However, the protease activity was rapidly declined beyond $23550^{\circ} \mathrm{C}$. As shown in Fig. $4 \mathrm{~B}$, the purified protease could retain $100 \%$ relative activity at 30 to $23650^{\circ} \mathrm{C}$ for $30 \mathrm{~min}$ and $60 \mathrm{~min}$, respectively. Similar effects of temperature on protease activity 237 have been reported. For example, the protease produced by B. subtilis Y-108 showed its 238 optimum temperature at $50^{\circ} \mathrm{C}$ and thermal stability at 25 to $50^{\circ} \mathrm{C}$ [13]. The protease from $B$. 
240 declined above $40^{\circ} \mathrm{C}$ [12].

241

242

\subsection{Substrate specificity} 251 reported by McConn et al.

subtilis RKY3 had its optimum temperature at $60^{\circ} \mathrm{C}$, and its thermal stability was rapidly

244 The purified protease was reacted with different substrates such as casein, BSA, soybean 245 flour, or gelatin. As shown in Table 2, casein was found to show the highest substrate 246 specificity (100\%) to the purified enzyme, followed by soybean flour (71.6\%) and BSA 247 (22.3\%). However, the enzyme could not assimilate gelatin as a substrate. McConn et al. [17] 248 previously reported that a neutral protease derived from $B$. subtilis was active in hydrolyzing 249 casein but its ability to hydrolyze gelatin and egg albumin was only limited. This result 250 suggests that the purified protease form B. subtilis FBL-1 show similar aspect of B. subtilis

\subsection{Effect of metal ions on protease activity}

255 The effect of metal ions on protease activity was shown in Table 3. The relative activity of 
protease in the presence of $10 \mathrm{mM} \mathrm{Mg}{ }^{2+}, \mathrm{Ca}^{2+}$, and $\mathrm{Mn}^{2+}$ were $41 \%, 30 \%$, and $23 \%$, respectively. Though the enzyme was significantly inhibited by $10 \mathrm{mM} \mathrm{Fe}{ }^{3+}, \mathrm{Fe}^{2+}$ led to activation of protease activity. Similar effect of metal ions on protease activity has been 259 reported. Proteases produced by B. tequilensis P15 [14], B. cereus SV1 [15], B. cereus 260 AK1871 [16], Bacillus sp. B001 [4], B. mojavensis A21 [18] and Bacillus sp. AK.1 [19] were 261 activated by presence of $\mathrm{Ca}^{2+}$. Some earlier reports have also showed that thermal stability of 262 protease was improved in the presence of $\mathrm{Ca}^{2+}[20]$. It may be explained by strengthening the 263 interactions inside protein molecules and by combining $\mathrm{Ca}^{2+}$ to autolysis site to prevent 264 autolysis and thermal unfolding [19, 21].

The effect of various chemicals such as surfactants, oxidants, and reductants on protease 269 activity was investigated. As shown in Table 4, the enzyme was stable in the presence of $1 \%$ 270 (v/v) nonionic surfactants like Tween 20, Tween 80, and Triton X-100. However, the enzyme 271 was inhibited by the presence of $1 \mathrm{mM}$ SDS as an anionic surfactant and $69 \%$ of the enzyme activity was inhibited by addition of $10 \mathrm{mM}$ SDS. In addition, hydrogen peroxide $\left(\mathrm{H}_{2} \mathrm{O}_{2}\right)$ and 
2-mercaptoethanol inhibited the protease activity by $12 \%$ and $36 \%$, respectively. Similar 274 effects of surfactants, oxidants, and reductants on protease activity have been reported.

275 Protease from B. tequilensis P15 was stable in the presence of nonionic surfactants such as 276 Tween 20, Tween 80, and Triton X-100, but it was inhibited in the presence of anionic 277 surfactant such as SDS by $47.4 \%$ [14]. However, the protease produced by B. mojavensis was 278 stable in the presence of high concentration SDS up to $1 \%(\mathrm{w} / \mathrm{v})[21]$.

\subsection{Effect of organic solvents on protease stability}

The relative activity of protease after exposure to organic solvents is shown in Table 5 .

Enzymes are generally inactivated in the presence of organic solvents such as 1-butanol, 284 benzene, $n$-hexane, 2-pronpanol, dimethyl sulfoxide, or ethyl alcohol. However, the protease 285 from B. subtilis FBL-1 was rarely inhibited by water-immiscible solvent such as $n$-hexane 286 even at $25 \%$ and $50 \%$. In addition, the enzyme was quite stable in the presence of 1-butanol 287 and DMSO at $25 \%$ and $50 \%$. Benzene and 2-propanol at 50\% significantly lowered the 288 enzyme activity to $69.4 \%$ and $42.8 \%$, respectively. According to the previous studies, the 
the enzyme from $B$. pumilus 115B [23] was stable in the presence of hexane and benzene, the

protease from B. tequilensis P15 [14] was unstable in the presence of hexane, and the enzyme

292 from B. cereus AK187 [16] was significantly unstable in the presence of butanol.

\subsection{Effect of inhibitors on protease activity}

The purified protease derived from $B$. subtilis FBL-1 was completely inhibited by the EDTA as a metalloprotease inhibitor (Table 6). The enzyme activity was almost reduced to $11 \%$ and

$3.67 \%$ in the presence of $2 \mathrm{mM}$ and $10 \mathrm{mM}$ EDTA, respectively, but it was nearly not

inhibited in the presence of PMSF and DIFP. Serine residue in the active site of the 300 proteinases is irreversibly acylated by PMSF or DIFP, which results in inactivation of the 301 enzymes. Therefore, the reagents such as PMSF or DIPF are serine protease inhibitors [24]. 302 Cysteine proteases are generally inactivated with oxidative agents, metal ions, or alkylating 303 agents. However, inhibition of metalloproteases is achieved with chelating agents (EDTA) or 304 sodium dodecyl sulfate [25]. Therefore, the results obtained here suggest that the purified 305 protease derived from $B$. subtilis FBL-1 should be considered to be a metalloprotease. 


\section{7 \\ 4. Conclusion}

309 The protease from B. subtilis FBL-1 was purified and characterization for industrial 310 application. The enzyme showed $\mathrm{pH}$ stability from 7.0 to 9.0 and thermostability from $30^{\circ} \mathrm{C}$ 311 to $50^{\circ} \mathrm{C}$. The protease activity was strongly activated by divalent metal ions. EDTA as a metal 312 chelator almost inhibited protease activity, but no inhibition was observed when DIFP was 313 added, suggesting that the protease from $B$. subtilis FBL-1 might be classified into a neutral 314 metalloprotease. In addition, the enzyme activity could be highly stable even in the presence 315 of nonionic surfactants, reducing agents, or organic solvents. It's stability against various 316 chemicals makes this enzyme a potential biocatalyst for industrial applications. These study 317 efforts need to get more knowledge on metalloproteases in B. subtilis for potential industrial

\section{$320 \quad$ References}

322 1. Hartley, B. S. (1960) Proteolytic enzymes. Annu. Rev. Biochem. 29: 45-72.

2. Liao, C. H. and D. E. McCallus (1998) Biochemical and genetic characterization of an 
extracellular protease from Pseudomonas fluorescens CY091. Appl. Environ. Microbiol.

64: 914-921.

3. Rao, M. B., A. M. Tanksale, M. S. Ghatge, and V. V. Deshpande (1998) Molecular and biotechnological aspects of microbial proteases. Microbiol. Mol. Biol. Rev. 62: 597-635.

4. Deng, A., J. Wu, Y. Zhang, G. Zhang, and T. Wen (2010) Purification and characterization of a surfactant-stable high-alkaline protease from Bacillus sp. B001. Bioresour. Technol. 101: 7111-7117.

5. Godfrey, T. and J. Reichelt (1984) Industrial Enzymology: The Application of Enzymes in Industry. The Nature Press, New York.

6. Li, Q., L. Yi, P. Marek, and B. L. Iverson (2013) Commercial proteases: present and future. FEBS Lett. 587: 1155-1163.

7. Kim, M., J. B. Si, and Y. J. Wee (2016) Identification of a newly isolated proteaseproducing bacterium, Bacillus subtilis FBL-1, from soil. Microbiol. Biotechnol. Lett. 44: 185-193.

8. Kim, M., J. B. Si, L. V. Reddy, and Y. J. Wee (2016) Enhanced production of extracellular proteolytic enzyme excreted by a newly isolated Bacillus subtilis FBL-1 through combined utilization of statistical design and response surface methodology. 
$341 \quad$ RSC Adv. 6: 51270-51278.

342 9. Folin, O. and V. Ciocalteu (1927) On tyrosine and tryptophane determinations in proteins.

$343 \quad$ J. Biol. Chem. 73: 627-650.

344 10. Smith, P. K., R. I. Krohn, G. T. Hermanson, A. K. Mallia, F. H. Gartner, M. D.

345 Provenzano, E. K. Fujimoto, N. M. Goeke, B. J. Olson, and D. C. Klenk (1985)

346 Measurement of protein using bicinchoninic acid. Anal. Biochem. 150: 76-85.

347 11. Laemmli, U. K. (1970) Cleavage of structural proteins during the assembly of the head $348 \quad$ of bacteriophage T4. Nature 227: 680-685.

349 12. Reddy, L. V. A., Y. J. Wee, and H. W. Ryu (2008) Purification and characterization of an 350 organic solvent and detergent-tolerant novel protease produced by Bacillus sp RKY3. J. $351 \quad$ Chem. Technol. Biotechnol. 83: 1526-1533.

352 13. Yang, J. K., I. L. Shih, Y. M. Tzeng, and S. L. Wang (2000) Production and purification 353 of protease from a Bacillus subtilis that can deproteinize crustacean wastes. Enzyme $354 \quad$ Microb. Technol. 26: 406-413.

355 14. Bose, A., V. Chawdhary, H. Keharia, and R. B. Subramanian (2014) Production and 356 characterization of a solvent-tolerant protease from a novel marine isolate Bacillus 357 tequilensis P15. Ann. Microbiol. 64: 343-354. 
15. Manni, L., K. Jellouli, R. Agrebi, A. Bayoudh, and M. Nasri (2008) Biochemical and molecular characterization of a novel calcium-dependent metalloprotease from Bacillus cereus SV1. Process Biochem. 43: 522-530.

16. Shah, K., K. Mody, J. Keshri, and B. Jha (2010) Purification and characterization of a solvent, detergent and oxidizing agent tolerant protease from Bacillus cereus isolated from the Gulf of Khambhat. J. Mol. Catal. B-Enzym. 67: 85-91.

17. McConn, J. D., D. Tsuru, and K. T. Yasunobu (1964) Bacillus Subtilis neutral proteinase. I. a zinc enzyme of high specific activity. J. Biol. Chem. 239: 3706-3715.

18. Haddar, A., R. Agrebi, A. Bougatef, N. Hmidet, A. Sellami-Kamoun, and M. Nasri (2009) Two detergent stable alkaline serine-proteases from Bacillus mojavensis A21: purification, characterization and potential application as a laundry detergent additive. 369 Bioresour. Technol. 100: 3366-3373.

370 19. Smith, C. A., H. S. Toogood, H. M. Baker, R. M. Daniel RM, and E. N. Baker (1999) 371 Calcium-mediated thermostability in the subtilisin superfamily: the crystal structure of 372 Bacillus Ak.1 protease at 1.8 å resolution. J. Mol. Biol. 294: 1027-1040.

373 20. Sellami-Kamoun, A., A. Haddar, H. Ali Nel, B. Ghorbel-Frikha, S. Kanoun, and M. 374 Nasri (2008) Stability of thermostable alkaline protease from Bacillus licheniformis RP1 
in commercial solid laundry detergent formulations. Microbiol. Res. 163: 299-306.

21. Beg, Q. K. and R. Gupta (2003) Purification and characterization of an oxidation-stable, thiol-dependent serine alkaline protease from Bacillus mojavensis. Enzyme Microb. Technol. 32: 294-304.

22. Divakar, K., J. D. A. Priya, and P. Gautam (2010) Purification and characterization of thermostable organic solvent-stable protease from Aeromonas veronii PG01. J. Mol. 


\section{$391 \quad$ Figure Legends}

393 Fig. 1. Chromatograms obtained by (A) DEAE-Cellulose ion-exchange chromatography and 394 (B) Sephadex G-75 gel filtration chromatography. Both columns were equilibrated with 100 $395 \mathrm{mM}$ Tris-HCl buffer (pH 7.0).

397 Fig. 2. SDS-PAGE of the purified protease produced by B. subtilis FBL-1. Lane 1, molecular 398 weight marker proteins; lane 2, crude extract; lane 3, ammonium sulfate fraction; lane 4, 399 DEAE-Cellulose fraction; lane 5, Sephadex G-75 fraction.

Fig. 3. Effect of $\mathrm{pH}$ on (A) protease activity and (B) stability. The buffer systems used were 402 as follows: $0.1 \mathrm{M}$ citric acid buffer for $\mathrm{pH}$ 3.0-5.0, $0.1 \mathrm{M}$ phosphate-citrate buffer for $\mathrm{pH}$ 5.0403 7.0, 0.1 M Tris-HCl buffer $\mathrm{pH}$ 7.0-9.0, and 0.1 M glycine-NaOH buffer for $\mathrm{pH}$ 9.0-12.0. The 404 highest enzyme activity was considered as $100 \%$, and error bars showed standard deviations 405 of triplicate samples.

Fig. 4. Effect of temperature on (A) protease activity and (B) stability. The highest enzyme 
408 activity was considered as $100 \%$, and error bars showed standard deviations of triplicate

409 samples.

410

10

11

12

13

14

15

16

17

18

19

20

21

22

23

24

25

26

27

28

29

30

31

32

33

34

35

36

37

38

39

40

41

42

43

44

45

46

47

48

49

50

51

52

53

54

55

56

57

58

59

60

61

62 
411 Table 1. Summary of the purification step for the proteolytic enzyme from Bacillus subtilis

412 FBL-1

\begin{tabular}{|c|c|c|c|c|c|}
\hline Purification steps & Total & Total & Specific & Recovery & Purification \\
\hline & protein & activity & activity & $(\%)$ & (fold) \\
\hline & (mg) & (U) & (U/mg) & & \\
\hline Crude extract & $7,073.0$ & $251,794.5$ & 35.6 & 100 & 1 \\
\hline$\left(\mathrm{NH}_{4}\right)_{2} \mathrm{SO}_{4}(30-$ & 175.4 & $17,795.3$ & 101.5 & 7.1 & 2.85 \\
\hline \multicolumn{6}{|l|}{$80 \%)$} \\
\hline DEAE-Cellulose & 3.9 & $12,937.1$ & $3,352.4$ & 5.1 & 94.17 \\
\hline Sephadex G-75 & 1.7 & $5,669.9$ & $3,378.1$ & 2.3 & 94.89 \\
\hline
\end{tabular}


415 Table 2. Substrate specificity of the purified protease from Bacillus subtilis FBL-1

Substrates $(1 \%, \mathrm{w} / \mathrm{v}) \quad$ Relative activity $(\%)$

Casein

$100 \pm 7.4$

Bovine serum albumin

$22.3 \pm 1.3$

Soybean flour

$71.6 \pm 4.3$

Gelatin 
418 Table 3. Effect of metal ions on protease activity

\begin{tabular}{|c|c|c|}
\hline \multirow[t]{2}{*}{ Metal ions } & \multicolumn{2}{|c|}{ Relative activity (\%) } \\
\hline & $1 \mathrm{mM}$ & $10 \mathrm{mM}$ \\
\hline None & $100 \pm 1.7$ & $100 \pm 1.6$ \\
\hline $\mathrm{Mg}^{2+}\left(\mathrm{MgSO}_{4}\right)$ & $118 \pm 12.9$ & $141 \pm 4.4$ \\
\hline $\mathrm{Fe}^{2+}\left(\mathrm{FeSO}_{4}\right)$ & $119 \pm 8.1$ & $110 \pm 3.6$ \\
\hline $\mathrm{Fe}^{3+}\left(\mathrm{FeCl}_{3}\right)$ & $125 \pm 4.7$ & $47 \pm 3.5$ \\
\hline $\mathrm{Mn}^{2+}\left(\mathrm{MnCl}_{2}\right)$ & $123 \pm 3.3$ & $123 \pm 6.5$ \\
\hline $\mathrm{NH}^{4+}\left(\mathrm{NH}_{4} \mathrm{Cl}\right)$ & $105 \pm 2.9$ & $108 \pm 4.6$ \\
\hline $\mathrm{Ca}^{2+}\left(\mathrm{CaCl}_{2}\right)$ & $116 \pm 0.8$ & $130 \pm 3.3$ \\
\hline $\mathrm{Ca}^{2+}\left(\mathrm{CaCO}_{3}\right)$ & $106 \pm 5.8$ & $112 \pm 2.1$ \\
\hline $\mathrm{K}^{+}(\mathrm{KCl})$ & $107 \pm 3.2$ & $116 \pm 3.0$ \\
\hline $\mathrm{Zn}^{+}(\mathrm{ZnCl})$ & $104 \pm 1.7$ & $93 \pm 4.2$ \\
\hline
\end{tabular}


420 Table 4. Effect of surfactants, oxidants, and reductants on protease activity

\begin{tabular}{|c|c|c|}
\hline Surfactants, oxidants, or reductants & Concentration & Relative activity (\%) \\
\hline None & - & $100 \pm 4.6$ \\
\hline Tween 20 & $1 \%(\mathrm{v} / \mathrm{v})$ & $77 \pm 1.2$ \\
\hline Tween 80 & $1 \%(\mathrm{v} / \mathrm{v})$ & $88 \pm 1.0$ \\
\hline Triton X-100 & $1 \%(\mathrm{v} / \mathrm{v})$ & $77 \pm 2.9$ \\
\hline \multirow[t]{2}{*}{ Sodium dodecyl sulfate (SDS) } & $1 \mathrm{mM}$ & $86 \pm 2.1$ \\
\hline & $10 \mathrm{mM}$ & $31 \pm 0.7$ \\
\hline $\mathrm{H}_{2} \mathrm{O}_{2}$ & $2 \%(\mathrm{v} / \mathrm{v})$ & $88 \pm 2.9$ \\
\hline 2-Mercaptoethanol & $2 \%(\mathrm{v} / \mathrm{v})$ & $64 \pm 3.7$ \\
\hline
\end{tabular}


422 Table 5. Effect of organic solvents on protease activity

\begin{tabular}{|c|c|c|}
\hline \multirow{2}{*}{ Solvents } & \multicolumn{2}{|c|}{ Relative activity (\%) } \\
\hline & $25 \%(\mathrm{v} / \mathrm{v})$ & $50 \%(\mathrm{v} / \mathrm{v})$ \\
\hline None & $100 \pm 2.4$ & $100 \pm 2.4$ \\
\hline 1-Butanol & $77.6 \pm 3.1$ & $77.4 \pm 5.8$ \\
\hline$n$-Hexane & $102.3 \pm 3.5$ & $100 \pm 8.1$ \\
\hline Benzene & $66.1 \pm 3.5$ & $30.6 \pm 1.0$ \\
\hline 2-Propanol & $75.8 \pm 4.1$ & $57.2 \pm 2.4$ \\
\hline Dimethyl sulfoxide (DMSO) & $79.3 \pm 3.2$ & $73.1 \pm 1.6$ \\
\hline Ethyl alcohol & $87.6 \pm 3.8$ & $61.2 \pm 3.6$ \\
\hline
\end{tabular}


424 Table 6. Effect of inhibitors on protease activity

\begin{tabular}{lll}
\hline Inhibitors & Concentration (mM) & Relative activity (\%) \\
\hline None & - & $100 \pm 2.94$ \\
Ethylene-diaminetetraacetic acid (EDTA) & 2 & $11 \pm 0.47$ \\
& 10 & $3.67 \pm 0.47$ \\
Diisoprophyl fluorophoshpahte (DIFP) & 0.1 & $86.33 \pm 3.68$ \\
Phenylmethly sulfonyl fluoride (PMSF) & 1 & $84.67 \pm 6.13$ \\
\hline
\end{tabular}



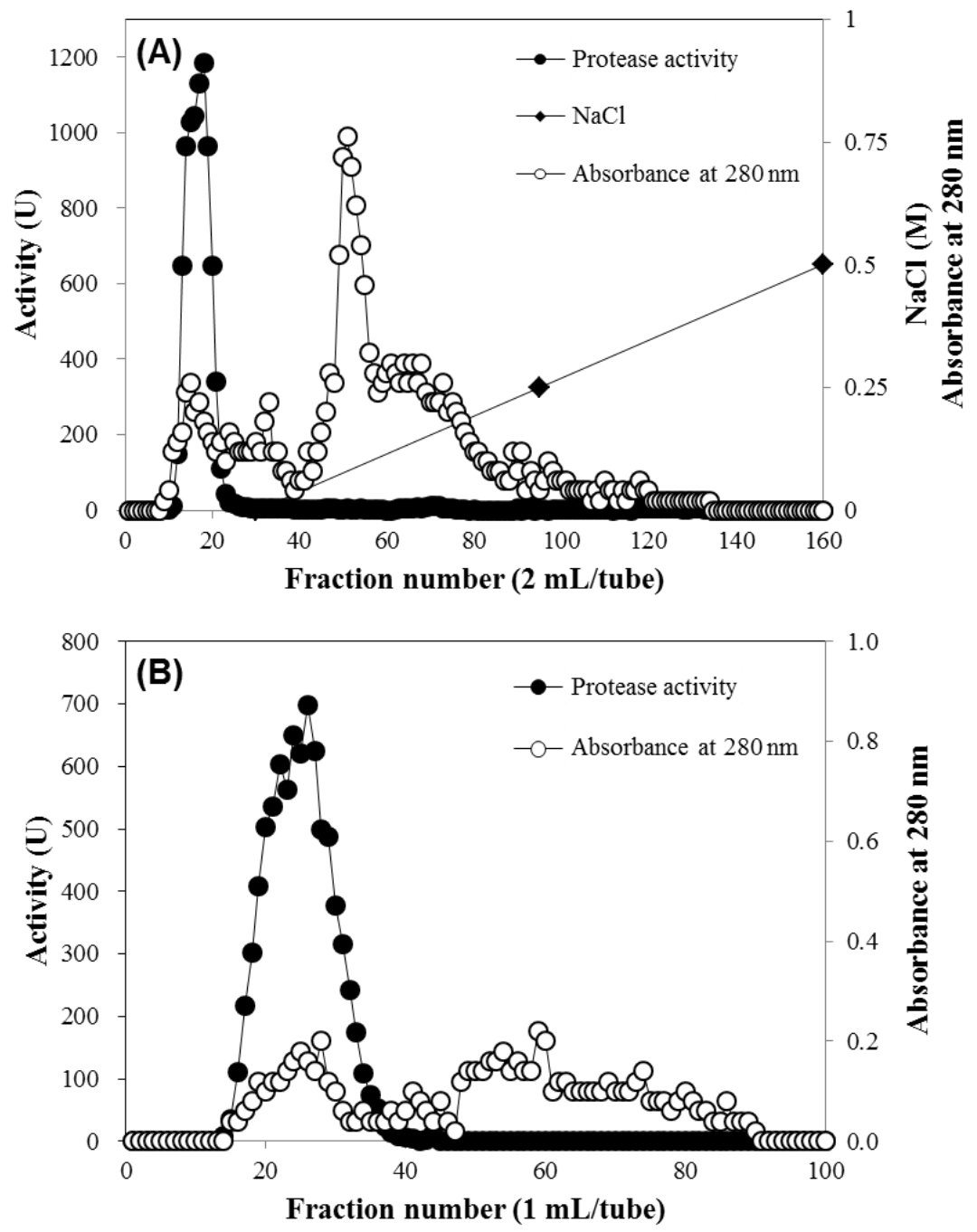
1

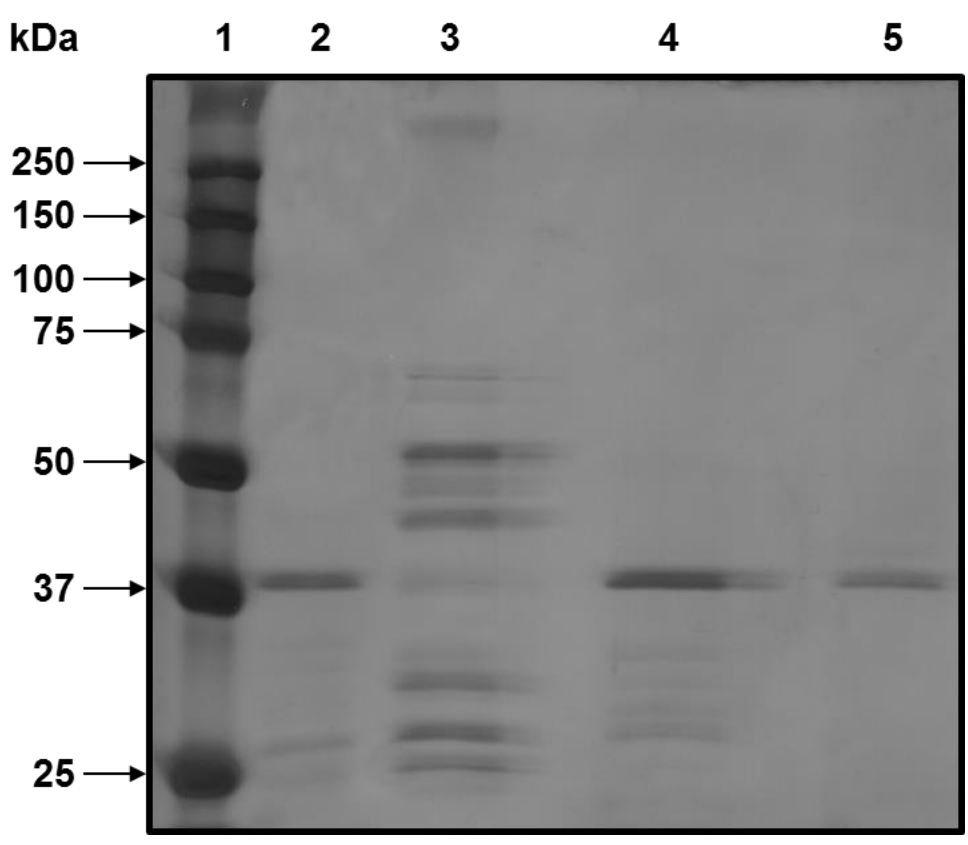

429

431 Fig. 2 
1

2

3

4

5

6

7

8

9
10

11

12

13

14

15

16

17

18

19

20

21

22

23

24

25

26

27

28

29

30

31

32

33

34

35

36

37

38

39

40

41

42

43

44

45

46

47

48

49

50

51

52

53

54

55

56

57

58

59

60

61

62

63

64

65
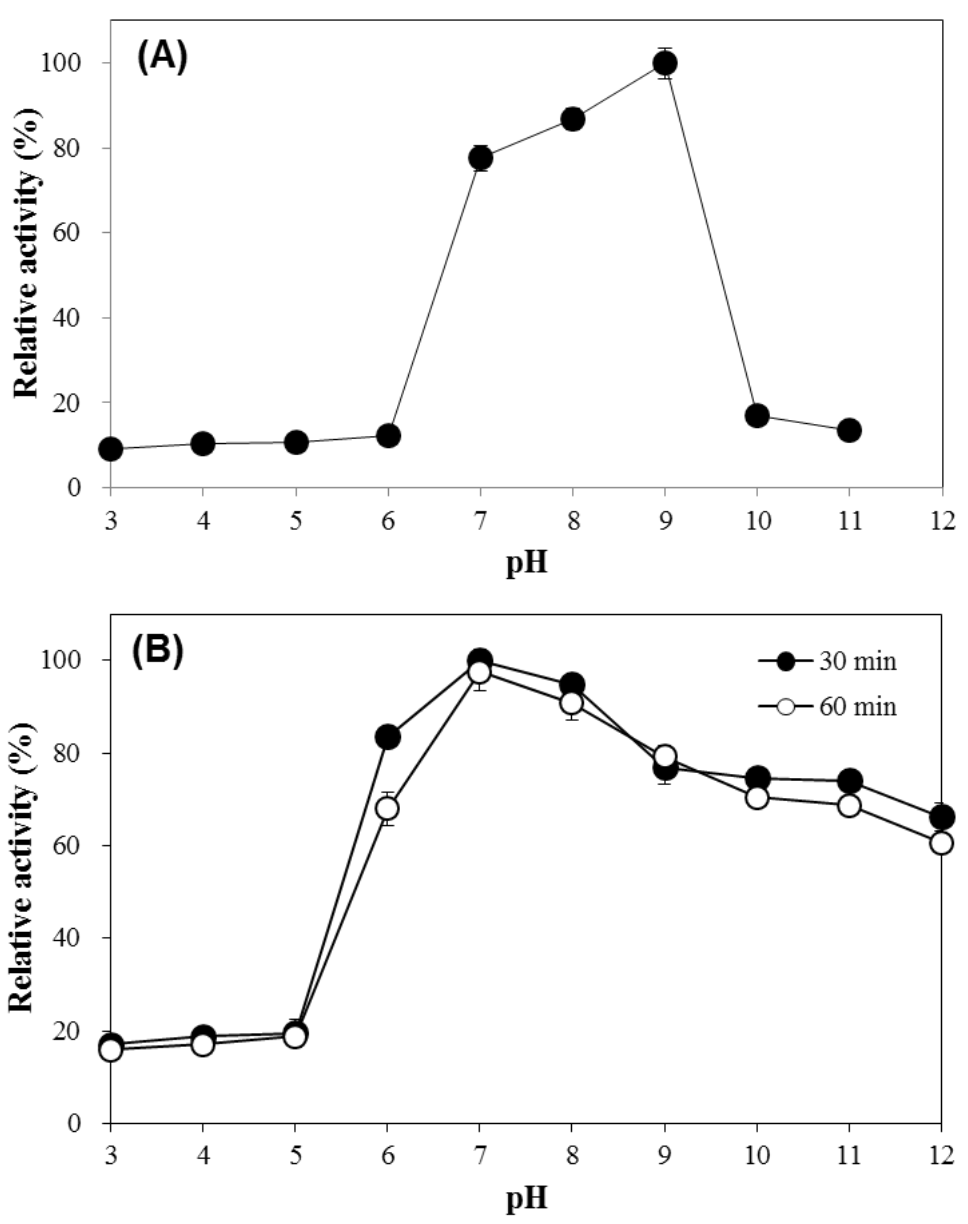

435 Fig. 3 
1

2

3

4

5

7

8

9

10

11

12

13

14

15

16

17

18

19

20

21

22

23

24

25

26

27

28

29

30

31

32

33

$34 \quad 438$

35

36

37

38

39

40

41

42

43

44

45

46

47

48

49

50

51

52

53

54

55

56

57

58

59

60

61

62

63

64

65
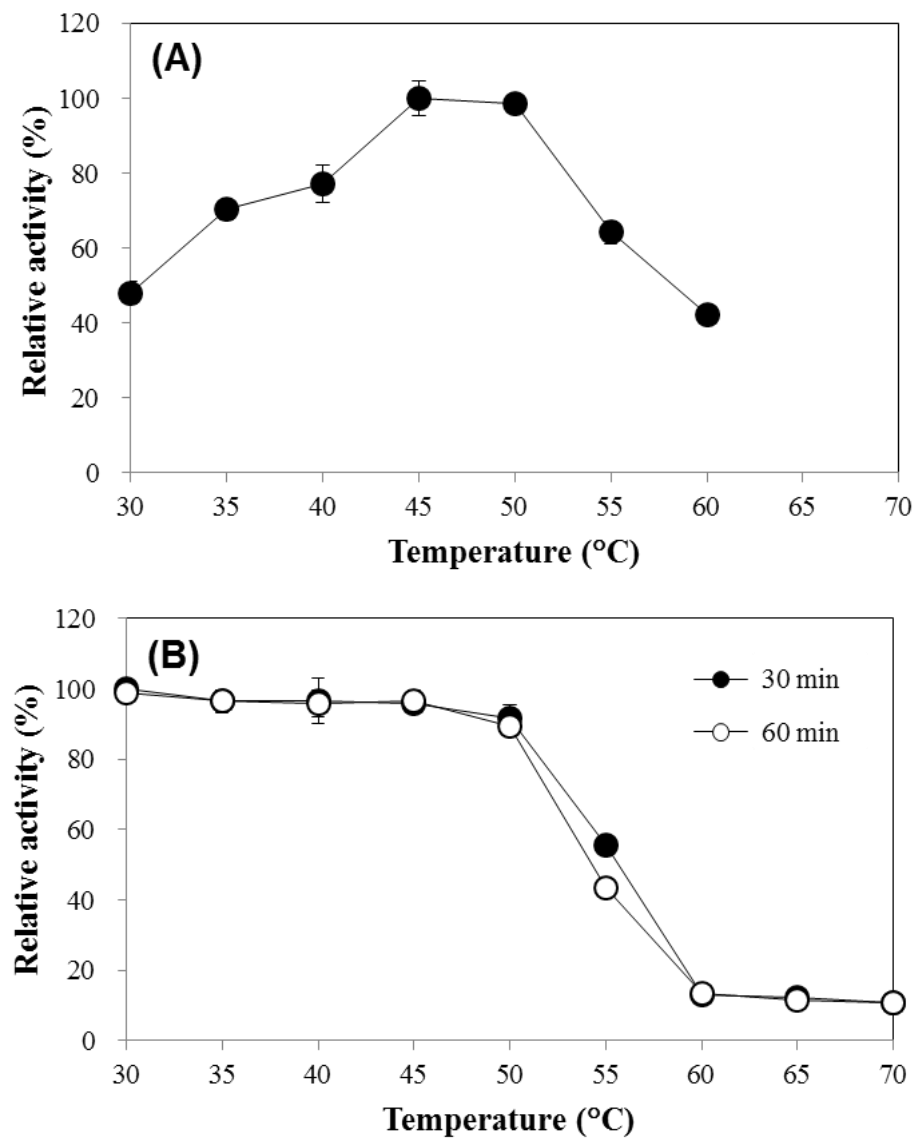

439 Fig. 4 